\title{
ON THE RESULTS OF BLAST-FURNACE PRACTICE WITH LIME INSTEAD OF LIMESTONE AS FLUX.
}

By the President, Charles cochrane, Esq.

To Sir Isaac Lowthian Bell we are indebted for a most carefully conducted series of experiments upon the Blast-Furnace, recorded in his work entitled "Chemical Phenomena of Iron Smelting." To M. Grüner is the scientific world further indebted for embodying in his "Études sur les Hauts-Fourneaux" the results of those experiments in the most carefully developed mathematical order and algebraical formulæ that blast-furnace practice has witnessed. Neither M. Valérius nor MM. Flachat Barrault and Petiet have approached Sir Lowthian Bell and M. Grüner in their exposition of the phenomena of the blast-furnace reactions; although, as happens in all scientific progress, those earlier works have been stepping stones to the great stride accomplished by Sir Lowthian Bell and by M. Grüner. It is true that Sir Lowthian Bell pointed out how the presence of carbonic acid in the gases escaping from the blastfurnace had a distinct bearing upon the economy of fuel consumed in the production of a unit of pig iron; but he further insisted on the fact, as he supposed, that there was an absolute limit to the attainable ratio of carbonic acid to carbonic oxide in the escaping gases, beyond which further economy was impossible, by reason of alleged reactions between these two gases as soon as ever that limit was reached. The limit he assigned was one volume of carbonic acid to two volumes of carbonic oxide; which is equivalent to a ratio by weight of three of carbonic acid to four of carbonic oxide or $\mathrm{CO}_{2}: \mathrm{CO}=0 \cdot 75: 1 \cdot 00$. M. Grüner gave, presumably for the first time, the maximum of perfection possible in any blast-furnace in terms of the maximum ratio of carbonic acid to carbonic oxide; but he seems too readily to have fallen in with Sir Lowthian 
Bell's idea that there was a practical limit to this ratio, by reason of the reactions which Sir L. Bell alleged took place when the limit was exceeded of one volume of carbonic acid to two of carbonic oxide.

The conclusion drawn by Sir L. Bell is believed by the writer to have been experimentally correct under the conditions under which he assumed the gases to exist in the blast-furnace; but the writer's practice has shown him that there are conditions hitherto unrecorded, which govern the attainable ratio of carbonic acid to carbonic oxide; and it has been his aim for many years past to arrive at the true law which governs the relations of these two gases, and the resulting economy or sacrifice of fuel in the blast-furnace. M. Grüner stated that the ratio of carbonic acid to carbonic oxide was the keynote of the position, and he was right; but it has needed years of practical experience, in the light of Sir Lowthian Bell's analytical experiments and of M. Griiner's inferences, to solve the problem.

There are two leading factors in the conduct of a blast-furnace, which are readily intelligible:- the combustion of carbon at the tuyeres into carbonic oxide wholly; and the rednction of the oxide of iron by the reaction of the carbonic oxide thus produced, so as to form carbonic acid, according to the well-known formula in the case of peroxide of iron, $\mathrm{Fe}_{2} \mathrm{O}_{3}+3 \mathrm{CO}=\mathrm{Fe}_{2}+3 \mathrm{CO}_{2}$ or $(28 \times 2+8 \times 3)$ $+3 \times(6+8)=56+3 \times(6+16)$. Now supposing there were no other reactions than these, and that there were needed $15 \mathrm{cwts}$. of pure carbon to produce $20 \mathrm{cwts}$. of pure iron, the ratio of carbonic acid to carbonic oxide would be found as follows:- $-15 \times 14$ $\div 6=35$ cwts. of carbonic oxide produced at the tuyeres; and according to the above formula, for every $56 \mathrm{cwts}$. of iron $42 \mathrm{cwts}$. of carbonic oxide would be required with production of $66 \mathrm{cwts}$. of carbonic acid. Hence for every $20 \mathrm{cwts}$. of pure iron there would be required $42 \times 20 \div 56=15 \mathrm{cwts}$. of carbonic oxide; and there would be produced $15 \times 66 \div 42=23.57 \mathrm{cwts}$. of carbonic acid. There would therefore be left $35-15=20 \mathrm{cwts}$. of carbonic oxide; and there would be formed $23.57 \mathrm{cwts}$. of carbonic acid ; and the ratio of these would be $\mathrm{CO}_{2}: \mathrm{CO}=23 \cdot 57: 20 \cdot 00=1 \cdot 18$. Now Sir Lowthian 
Bell's assertion is that such a ratio would be impossible, because the moment the limiting ratio of 0.75 is exceeded, the immediate effect would be to cause a re-conversion of carbonic acid into carbonic oxide, and so to undermine the economy due to such a ratio as the foregoing of $1 \cdot 18$, by the unburning of carbon oxidised to its highest degree. Yet he himself gives an illustration of Styrian furnaces where pig-iron is made with from 12 to $15 \mathrm{cwts}$. of charcoal per 20 cwts. of pig-iron produced: so that on the merits of the case there would seem to be something wrong in his deductions. Although as a matter of fact so high a value as 0.75 for the ratio of carbonic acid to carbonic oxide has not been attained with Cleveland ironstone, the author purposes showing that the cause is to be songht deeper than in the mere arbitrary limit assigned to the ratio of carbonic acid to carbonic oxide, and is to be found in reactions of carbonic acid upon red-hot carbon, and in the consequent production of carbonic oxide, so that the ratio $\mathrm{CO}_{2}: \mathrm{CO}$ is essentially an effect and not a cause.

In a blast-furnace the perfection of work is that carbonic acid, having once been formed in the process of reduction, should never be allowed to come into contact with red-hot coke; for the immediate reaction between carbonic acid and carbon at a red heat is to convert the carbonic acid into carbonic oxide with most destructive waste of fuel. Thus the units of heat developed by one unit (or cwt.) of carbon burnt into carbonic oxide only are 2,473 (centigrade), whereas the units of heat developed by one unit of carbon burnt into carbonic acid are 8,080; hence the units of heat developed by one unit of carbon in carbonic oxide burnt into carbonic acid are $8,080-2,473=5,607$. It will thus be seen that, if by any unfarourable reaction in the furnace, such as happens when carbonic acid finds itself in the presence of red-hot coke, any carbonic acid once formed becomes re-converted into carbonic oxide, the unburning of the carbonic acid to carbonic oxide must be accompanied not only by the absorption of carbon but also by serious loss of heat. The reaction which takes place is represented by the formula $\mathrm{CO}_{2}+\mathrm{C}=2 \mathrm{CO}$; in which for every unit of 
carbon in the carbonic acid a unit of carbon of the coke is dissolved and becomes carbonic oxide; whilst the tuit of carbonic acid becomes two units of carbonic oxide by the absorption of the second equivalent of carbon. Just as one unit of carbon as carbonic oxide develops 5,607 heat-units in becoming carbonic acid, so one unit of carbon as carbonic acid in going back to carbonic oxide will absorb 5,607 heat-units; which is equal to the combustion of $5,607 \div 2,473$ $=2 \cdot 26$ units of carbon burnt into carbonic oxide, of which 1 unit of carbon has absolutely disappeared by absorption in the process, leaving 1.26 units, to be supplied and burnt into carbonic oxide at the tuyeres by means of the oxygen in the blast, to compensate for the balance of loss incurred in the region of the furnace in which the reaction has taken place: because by hypothesis the carbonic acid has been evolved or come into contact with red-hot coke under conditions under which it could not exist as carbonic acid. To make the ultimate result if necessary yet clearer, the absorption of the one unit of carbon by the carbonic acid to form carbonic oxide will develop 2,473 heat-units, while the re-conversion of the carbonic acid to carbonic oxide will subtract from the furnace 5,607 heatunits: so that the balance will be a loss of $5,607-2,473=3,134$ heat-units, which represent $3,134 \div 2,473=1 \cdot 26$ units of carbon burnt into carbonic oxide. Hence there is a total loss to the efficiency of the furnace of $1 \cdot 26+1 \cdot 00=2 \cdot 26$ units of carbon burnt into carbonic oxide for every unit of carbon once existing as carbonic acid which shall have been re-converted into carbonic oxide.

When limestone is employed as a flux there are two sources of carbonic acid:- firstly that contained in the carbonate of lime $\mathrm{CaO} \mathrm{CO}_{2}$, which has necessarily to be evolved in contact with red-hot coke, because at less than a red heat it is impossible to separate the carbonic acid from the lime; and secondly that evolved in the process of reduction of the ore or ironstone, which, if previously calcined so as to becomo peroxide of iron, undergoes the following reaction: $\mathrm{Fe}_{2} \mathrm{O}_{3}+3 \mathrm{CO}=\mathrm{Fe}_{2}+3 \mathrm{CO}_{2}$. Now according to the construction of the furnace, and the more or less imperfect appliances at command, much or little of the latter, which will be called the 
carbonic acid of reduction, may be evolved in the same red-hot region in which the carbonic acid from the flux is driven off. In old furnaces of very small capacity, extravagant waste of fuel took place from this very cause, namely the evolution of carbonic acid of reduction in the red-hot region, owing to the plunging of the ironstone down into that region before its complete reduction had been effected in a higher and cooler region. How great could be the mischief will appear by assuming the extreme case of a furnace so badly constructed that the whole of the reduction of the peroxide of iron should take place in the red-hot region. From the formula $\mathrm{Fe}_{2} \mathrm{O}_{3}+3 \mathrm{CO}=\mathrm{Fe}_{2}+3 \mathrm{CO}_{2}$, or $(2 \times 28)+3 \times 8+3 \times(6+8)=$ $(2 \times 28)+3 \times(6+16)$, it will be seen that for the reduction of 56 ewts. of iron there are required $18 \mathrm{cwts}$. of carbon as carbonic oxide; and $56: 20:: 18: 6 \cdot 43$; therefore 6.43 cwts. of carbon are required for the reduction of $20 \mathrm{cwts}$. of iron from its assumed condition of peroxide. But inasmuch as $20 \mathrm{cwts}$. of pig-iron contain only $18 \cdot 80$ of pure iron, the carbon required per ton of pig-iron will be $6.43 \times$ $18 \cdot 80 \div 20=6.04 \mathrm{cwts}$. Now suppose the whole of this carbon, which should in a perfect furnace pass away as carbonic acid, became re-converted into carbonic oxide; it would first absorb 6.04 cwts. of carbon for conversion into carbonic oxide, according to the reaction $\mathrm{CO}_{2}+\mathrm{C}=2 \mathrm{CO}$; and the heat to be furnished at the tuyeres would be $6 \cdot 04 \times 1 \cdot 26=7 \cdot 61$ cwts. of carbon burnt into carbonic oxide. Hence a total loss would arise of $7 \cdot 61+6 \cdot 04=13 \cdot 65$ cwts. of carbon per ton of pig-iron.

It was in the direction of reducing this mischievous tendency that, at Middlesbrough especially, important economies ensued on increasing the capacity of the blast-furnace from 6,000 or 7,000 cubic feet to 20,000 cubic feet or more. Thereby more time was given for the reduction of the ironstone: so that it became more possible to secure, in the analysis of the escaping gases when employing limestone as flux, a nearer approach to the presence of the entire quantity of carbonic acid of reduction and in certain cases even the entire quantity. Indeed M. Grüner was quick to discover in Sir Lowthian Bell's experiments the presence in some cases of a little more carbonic acid than was due to the possible formation of 
carbonic acid by the reduction of all the ironstone; and the excess must have proceeded from the evolution of carbonic acid from the limestone. As the writer has himself on several occasions since confirmed M. Grüner's observation, he now deems such increase of carbonic acid beyond the carbonic acid of reduction to be the result of a trifling wave of carbonic acid displaced from the surface of the limestone just before it plunges into the red-hot coke region. The amount is so little as not to disturb the main conclusion that the carbonic acid of the flux takes up a weight of carbon practically equal to that which it already contains. Nor must it be lost sight of that in thus taking up earbon and becoming $2 \mathrm{CO}$ the result it produces is not altogether prejudicial; for the carbonic oxide so formed enriches the deoxidising gas of the furnace, and promotes the more complete deoxidation of the ironstone in the cooler region above, so as to make it possible to attain to a perfect reduction thereof without absorption of carbon by carbonic acid of reduction.

At this stage it may be interesting to refer to the effect of displacing the carbonic acid from the flux by calcining the latter before employing it in the blast-furnace. The following Tables 1 and 2 present a comparison between the results obtained at the same furnace under the two different conditions, and will fully illustrate the benefit to be obtained under favourable conditions by the substitution of lime $\mathrm{CaO}$ for limestone $\mathrm{CaO} \mathrm{CO}$ in a blast-furnace of capacity adapted to the materials employed, although there may seem room for a little regret that the balance of heat received (Table 1) and heat expended (Table 2) is not somewhat closer than here appears.

In these comparative accounts of receipts and expenditure of heat it will be noticed that, in working on limestone, the expenditure falls short by 0.72 ewt. of carbon of the total heat received in fuel and heated blast, and reckoned in carbon burnt to carbonic oxide; whilst in working on lime, the expenditure account shows an excess of 0.81 cwt. of carbon over that which was received. These are errors on either side, amounting to $2 \frac{1}{2}$ and 3 per cent. respectively, to which calculations of this kind are liable, 
TABLE 1.-Ormesby Iron Works, Middlesbrough. Blast-Furnace of 20,454 cubic feet capacity, and 76 feet height. Comparison between working on Limestone and on Lime respectively as flux.

\begin{tabular}{|c|c|c|c|c|}
\hline \multicolumn{3}{|c|}{$\begin{array}{l}\text { SUPPLY OF HEAT } \\
\text { per ton of pig-iron made. }\end{array}$} & $\begin{array}{l}\text { Work } \\
\text { Lime- } \\
\text { stone. }\end{array}$ & $\begin{array}{l}\text { ing on } \\
\text { Lime. }\end{array}$ \\
\hline \multirow{2}{*}{$\begin{array}{l}\text { Chemical Composition } \\
\text { of the } \\
\text { Escaping Gases. }\end{array}$} & By Volume & $\left\{\begin{array}{r}\text { Nitrogen } \mathrm{N} \\
\text { Carbonic Acid } \mathrm{CO}_{2} \\
\text { Carbonic Oxide OO } \\
\text { Hydrogen } \mathrm{H}\end{array}\right.$ & $\begin{array}{c}\text { Per cent } \\
58 \cdot 28 \\
9 \cdot 25 \\
30 \cdot 89 \\
1 \cdot 58\end{array}$ & $\begin{array}{c}\text { Per cent. } \\
59 \cdot 90 \\
9 \cdot 79 \\
28 \cdot 95 \\
1 \cdot 36\end{array}$ \\
\hline & By Weight & $\left\{\begin{array}{r}\text { Nitrogen } \mathrm{N} \\
\text { Carbonic Acid } \mathrm{CO}_{2} \\
\text { Carbonie Oxide } \mathrm{CO} \\
\text { Hydrogen } \mathbf{H}\end{array}\right.$ & $\begin{array}{r}56 \cdot 19 \\
14 \cdot 04 \\
29 \cdot 66 \\
0 \cdot 11\end{array}$ & $\begin{array}{r}57 \cdot 43 \\
14 \cdot 80 \\
27 \cdot 68 \\
0 \cdot 09\end{array}$ \\
\hline \multicolumn{3}{|c|}{$\begin{array}{l}\text { Ratio of } \mathrm{CO}_{2} \text { to } \mathrm{CO} \text { by weight } \\
\text { Temperature of Blast } \quad \text { Fahr. } 14 \dot{85^{\circ}} \text { and } 1409^{\circ}=\text { ratio } \\
\text { Temperature of Escaping Gases, Fahr. } 621^{\circ} \text { and } 574^{\circ}=\text { centig. }\end{array}$} & $\begin{array}{l}0.473 \\
807^{\circ} \\
327^{\circ}\end{array}$ & $\begin{array}{l}0 \cdot 535 \\
765^{\circ} \\
301^{\circ}\end{array}$ \\
\hline \multirow{2}{*}{\multicolumn{3}{|c|}{ 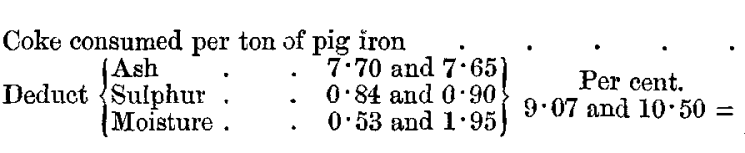 }} & $\begin{array}{l}\text { Cwts. } \\
23 \cdot 28\end{array}$ & $\begin{array}{l}\text { Cwts. } \\
19 \cdot 49\end{array}$ \\
\hline & & & $2 \cdot 09$ & \\
\hline \multicolumn{3}{|c|}{ Net Carbon in coke consumed per ton of pig iron } & $21 \cdot 19$ & $17 \cdot 44$ \\
\hline \multicolumn{3}{|c|}{ Limestone consumed per ton of pig iron $\cdot \begin{array}{llll} & \cdot & \cdot & \cdot\end{array}$} & $13 \cdot 18$ & $* 7 \cdot 86\}$ \\
\hline \multicolumn{3}{|c|}{ Deduct foreign matter in flux $3 \frac{1}{2}$ and $3 \cdot 71$ per cent. } & $0 \cdot 46$ & 0.45 \\
\hline \multicolumn{3}{|c|}{ Net pure Carbonate of Lime $\mathrm{CaO} \mathrm{CO}$} & $12 \cdot 72$ & $11 \cdot 83$ \\
\hline \multicolumn{3}{|c|}{$\begin{array}{l}\text { Carbon contained in flux, } 12 \cdot 72 \times 6 \div 50 \text { and } 0 \cdot 79 \times 6 \div 22 \\
\text { Total Carbon supplied into furnace per ton of pig iron, } \\
21 \cdot 19+1 \cdot 52 \text { and } 17 \cdot 44+0 \cdot 22 \\
\text { Deduct Carbon absorbed by pig iron }: . \\
\end{array}$} & $\begin{array}{r}1 \cdot 52 \\
22 \cdot 71 \\
0 \cdot 60\end{array}$ & $\begin{array}{r}* 0 \cdot 22 \\
17 \cdot 66 \\
0 \cdot 60\end{array}$ \\
\hline \multicolumn{3}{|c|}{$\begin{array}{c}\text { Net Carbon for producing joint } \mathrm{CO}_{2} \text { and } \mathrm{CO} \\
\text { (continued on next page) }\end{array}$} & $22 \cdot 11$ & $17 \cdot 06$ \\
\hline
\end{tabular}

* When working on lime, the actual weight of flux charged into the furnace per ton of pig iron made was 7.86 cwts. of impure lime, resulting from the calcination of 12.28 ewts. of raw limestone. The latter was fomd by analysis to contain 3.71 per cent. of foreign matter, amounting therefore to $0.45 \mathrm{cwt}$; and the net pure carbonate of lime was accordingly $12.28-0.45=11.83 \mathrm{cwts}$. of $\mathrm{CaO} \mathrm{CO}$, whjch contained $11.83 \times 22 \div 50=5 \cdot 21$ cwts. of $\mathrm{CO}_{2}$. But instead of the whole of this $\mathrm{CO}_{2}$ being expelled from the limestone in the calcining kiln, the actual weight driven of was only $12 \cdot 28-7 \cdot 86=4 \cdot 42$ cwts. Consequently there remained in the lime used as flux $5 \cdot 21-4 \cdot 42=0 \cdot 79 \mathrm{cwt}$. of $\mathrm{CO}_{2}$; and this unexpelled $\mathrm{CO}_{2}$ contained $0.79 \times 6 \div 22=0.22 \mathrm{cwt}$. of carbon, which corresponds with $1.83 \mathrm{cwt}$. of $\mathrm{CaO} \mathrm{CO}_{2}$. 


\section{TABLE I (continued).}

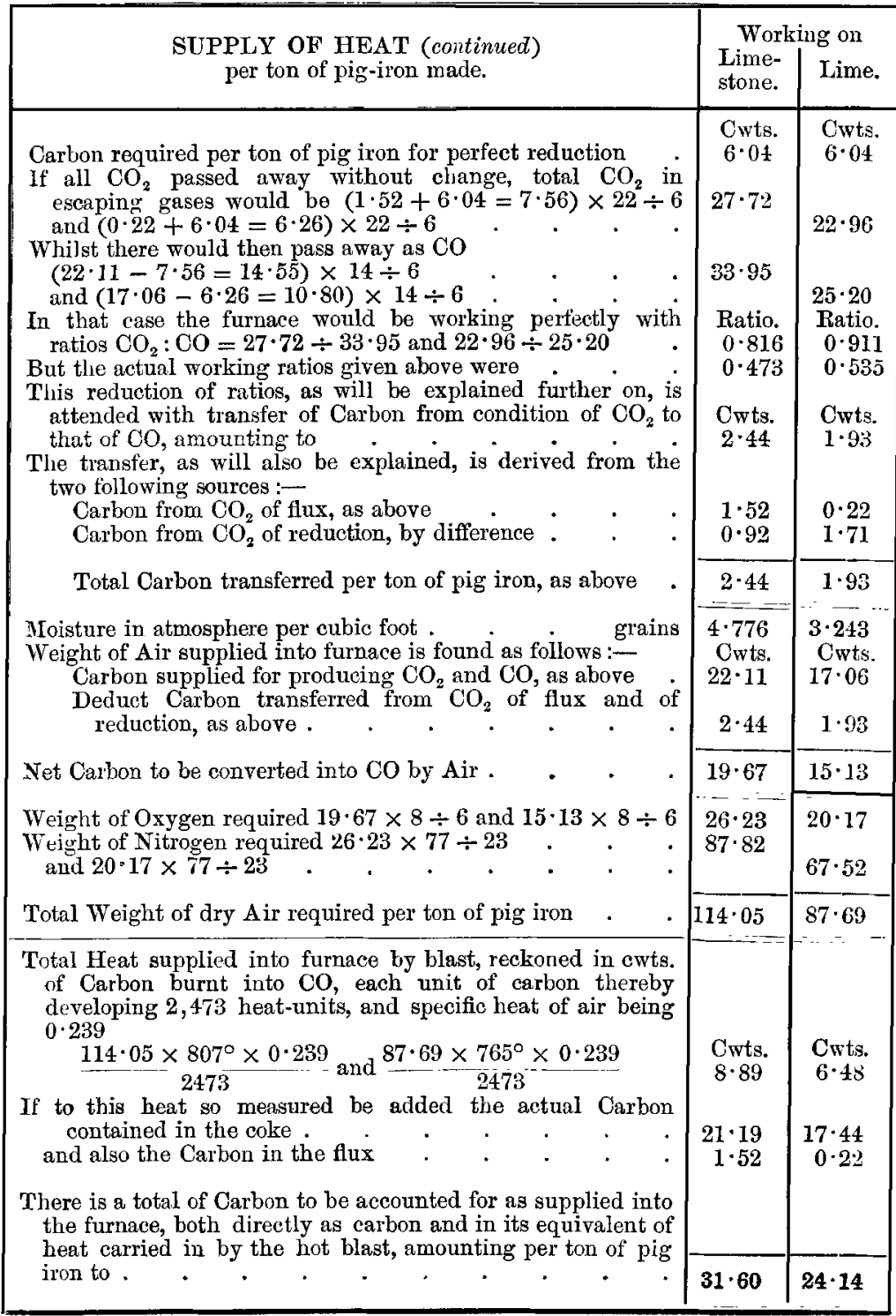


TABLE 2,-Ormesby Iron Works, Middlesbrough. Blast-Furnace of 20,454 cubic feet capacity, and 76 feet height. Comparison between working on Limestone and on Lime respectively as flux.

\begin{tabular}{|c|c|c|}
\hline \multirow{2}{*}{$\begin{array}{l}\text { EXPENDITURE OF HEAT } \\
\text { per ton of pig-iron made. }\end{array}$} & \multicolumn{2}{|c|}{ Working on } \\
\hline & $\begin{array}{l}\text { Lime- } \\
\text { stone. }\end{array}$ & Lime. \\
\hline $\begin{array}{l}\text { Gases escaping at tunnel head are found as follows :- } \\
\text { Net Carbon for producing } \mathrm{CO}_{2} \text { and } \mathrm{CO} \text {, as before } \\
\text { Deduct Carbon escaping in } \mathrm{CO}_{2}, 6 \cdot 04-0.92 \text { and } 6 \cdot 04-1 \cdot 71\end{array}$ & $\begin{array}{r}\text { Cwts. } \\
22 \cdot 11 \\
5 \cdot 12\end{array}$ & $\begin{array}{r}\text { Owts. } \\
17 \cdot 06 \\
4 \cdot 33\end{array}$ \\
\hline Leaves Carbon escaping in CO & $16 \cdot 99$ & $12 \cdot 73$ \\
\hline $\begin{array}{l}\mathrm{CO}_{2} \text { escaping } 5 \cdot 12 \times 22 \div 6 \text { and } 4 \cdot 33 \times 22 \div 6 \\
\mathrm{CO} \text { escaping } 16 \cdot 99 \times 14 \div 6 \text { and } 12 \cdot 73 \times 14 \div 6 \\
\text { Nitrogen escaping, as before } .\end{array}$ & $\begin{array}{l}18 \cdot 77 \\
39 \cdot 64 \\
87 \cdot 82\end{array}$ & $\begin{array}{l}15 \cdot 88 \\
29 \cdot 70 \\
67 \cdot 52\end{array}$ \\
\hline Total Weight of dry Gases escaping & $146 \cdot 23$ & $113 \cdot 10$ \\
\hline $\begin{array}{l}\text { Heat carried away by waste gases, reckoned in cwts. of Carbon } \\
\text { burnt into CO, each unit of earbon thereby developing } 2,473 \\
\text { heat-units, and specific heat of escaping gases being } 0.237 \\
146 \cdot 23 \times 327^{\circ} \times 0 \cdot 237 \\
\frac{113 \cdot 10 \times 301^{\circ} \times 0 \cdot 237}{2473} \text { and } \frac{2473}{13}\end{array}$ & $\begin{array}{r}\text { Cwts. } \\
4 \cdot 58\end{array}$ & $\begin{aligned} \text { Cwts. } \\
3 \cdot 26\end{aligned}$ \\
\hline Carbon absorbed by pig iron, as before & $0 \cdot 60$ & $0 \cdot 60$ \\
\hline $\begin{array}{l}\text { Carbon absorbed by } \mathrm{CO}_{2} \text { of flux } \\
\text { Carbon absorbed by } \mathrm{CO}_{2} \text { of reduction } 0.92 \text { and } 0.22 \\
0\end{array}$ & $2 \cdot 44$ & $1 \cdot 93$ \\
\hline $\begin{array}{l}\text { Extra Carbon needed to be burnt into } \mathrm{CO} \text { at tuyeres for } \\
\text { meeting loss of heat due to unburning of } \mathrm{CO}_{2} \text { into } \mathrm{CO} \text {, } \\
2.44 \times 1.26 \text { and } 1.93 \times 1.26 \text {. }\end{array}$ & $3 \cdot 07$ & $2 \cdot 43$ \\
\hline $\begin{array}{l}\text { Heat required to drive off } \mathrm{CO}_{2} \text { from flux, reckoned in cwts. of } \\
\text { Carbon burnt into } \mathrm{CO} \text {, each unit of flux requiring } 373 \cdot 5 \\
\text { heat-units to drive off } \mathrm{CO}_{2} \text {, }\end{array}$ & & \\
\hline $12 \cdot 72 \times 373 \cdot 5 \div 2473$ and $1 \cdot 83 \times 373 \cdot 5 \div 2473$ & $1 \cdot 92$ & $\begin{array}{r}0 \cdot 27 \\
0 \cdot 72\end{array}$ \\
\hline $\begin{array}{l}\text { Decomposition of Moisture in blast } \\
\text { Carbon remaining as } \mathrm{CO}_{2} \text { and passing away as such in } \\
\text { escaping gases is } 6.04-0.92 \text { and } 6.04-1 \cdot 71 \\
\text { The Slag, weighing about } 32 \text { cwts. per ton of pig iron, requires } \\
\text { for its melting } 550 \text { heat-units per unit of slag, or }\end{array}$ & $5 \cdot 1$ & $4 \cdot 33$ \\
\hline burnt to $\mathrm{CO}^{\circ}$ & 0 & $7 \cdot 11$ \\
\hline & 0.90 & $0 \cdot 90$ \\
\hline t by tuyere water, radiation & & 0.09 \\
\hline $\begin{array}{l}\text { Sundres, including loss of heat oy tuyere water, radiation } \\
\text { from sides of furnace and tuyere houses, \&e. }\end{array}$ & $3 \cdot 78$ & $3 \cdot 30$ \\
\hline $\begin{array}{l}\text { Total Carbon accounted for as expended : } \\
\text { Error }\end{array}$ & $\begin{array}{r}30 \cdot 88 \\
+0 \cdot 72 \\
\end{array}$ & $\begin{array}{r}24 \cdot 95 \\
-0 \cdot 81\end{array}$ \\
\hline Total Carbon to be accounted for as received & $31 \cdot 60$ & $24 \cdot 14$ \\
\hline $\begin{array}{l}\text { Consumption of calcined Ironstone per ton of pig iron } \\
\text { Make of Pig Iron per month } \\
\text { Quality of Pig Iron } \\
\text { Blast, presure per square inch at tuyeres } \\
\text { Area of Tuyeres }\end{array}$ & $\begin{array}{c}50 \cdot 13 \\
2141 \\
3 \cdot 25 \\
3 \cdot 87 \\
142\end{array}$ & $\begin{array}{c}50 \cdot 00 \\
2453 \\
3 \cdot 31 \\
3 \cdot 73 \\
142\end{array}$ \\
\hline
\end{tabular}


owing to the impossibility of recording accurately all the conditions under which a blast-furnace works. Imperfectly calcined ironstone for instance will contain more or less carbonic acid, which if at the surface will pass away as such, but if imprisoned in the core of a large piece of ironstone will descend into the red-hot region of the blast-furnace, there to be liberated with absorption of carbon and resultant loss of heat. Such fluctuations in the ironstone would produce some influence upon the ratio of carbonic acid to carbonic oxide; but all things considered, the above exrors of 0.72 and 0.81 cwt. respectively might fairly be spread over the whole of the expenditure account, indeed probably over both receipt and expenditure accounts, and so become inappreciable whilst leaving the salient points of the account undisturbed.

It will be seen that when working on lime, with even an imperfect calcination of the flux, an economy was obtained of $21 \cdot 19-17 \cdot 44=3 \cdot 75$ cwts. of carbon; whereas the theoretical saving should have been only $2 \cdot 94 \mathrm{cwts}$. of carbon, according to the weight of carbon in the carbonic acid displaced from the flux, namely $(1 \cdot 52-0 \cdot 22=1 \cdot 30) \times 1 \cdot 26+1 \cdot 30=2 \cdot 94$.

The calculation which needs explanation in Table 1 is the one whereby, from an analysis of the gases and from a knowledge of the carbon consumed per ton of pig-iron and of the unexpelled carbonic acid in the flux, it is possible to arrive at the exact mischief done in the red-hot coke region by each of the two sources of that mischief, namely the carbonic acid of reduction and the carbonic acid from the flux. In his last paper read before this Institution in January 1883 the author showed how this could be accomplished by a laborious method of calculation and by special tables; but continued study has enabled him to simplify the calculation, and by a simple algebraical formula to test the effective working of a blastfurnace by accounting in the form of an expenditure column for every unit of carbon consumed, whether in the heating of the blast or in the carbon burnt within the furnace. His own practice is to account in this expenditure for all fuel by reducing it to units of 
carbon burnt to carbonic oxide, each unit thereby developing 2,473 centigrade units of heat. In this way he hopes to have made a complicated problem clear.

Taking from Table 1 the ratio 0.473 determined by analysis as that of carbonic acid to carbonic oxide in the escaping gases when working on limestone, we begin by ascertaining what this ratio should have been, had there been no re-conversion whatever of carbonic acid into carbonic oxide. Then would the furnace have worked perfectly, and the ratio would have been found as follows. The net carbon arailable for producing joint carbonic acid and carbonic oxide has been found in the foregoing statement to be $22 \cdot 11 \mathrm{cwts}$ per ton of pig-iron. In perfect work all carbonic acid should pass away as such; and the total quantity produced in the furnace will be that from the $6.04 \mathrm{cwts}$. of carbon for the reduction of the ironstone and that from the $1.52 \mathrm{cwt}$. of carbon in the flux, namely:-

Carbon for reduction $\quad 6 \cdot 04 \times 22 \div 6=22 \cdot 15 \mathrm{cwts}$. of carbonic acid.

Carbon of flux . . $1.52 \times 22 \div 6=5 \cdot 57 \mathrm{cwts}$ of carbonic acid.

Total Carbon . . $\overline{7 \cdot 56} \times 22 \div 6=\overline{27 \cdot 72} \mathrm{cwts}$. of carbonic acid.

If these $7 \cdot 56$ cwts. of carbon all appeared as carbonic acid in the escaping gases, the balance should pass away as carbonic oxide, namely $22 \cdot 11-7 \cdot 56=14 \cdot 55 \times 14 \div 6=33.95 \mathrm{cwts}$. of carbonic oxide. Therefore the perfect ratio of carbonic acid to carbonic oxide would be $27 \cdot 72 \div 33 \cdot 95=0 \cdot 816$; but the actual ratio determined by analysis was only 0.473 , and has been lowered from the perfect to the actual by the transfer of a certain amount of carbon from the condition of carbonic acid to that of carbonic oxide. Let $x$ be the weight of the carbon so changed; then from the total carbonic acid possible in perfect work there will have been subtracted $\frac{22}{6} x$, and to the total carbonic oxide possible in perfect work there will have been added $\frac{14}{6} x$. Hence the new ratio of carbonic acid to carbonic oxide will be $\left(27 \cdot 72-\frac{22}{6} x\right) \div\left(33.95+\frac{14}{6} x\right)=0.473$. Whenee $x=2.44 \mathrm{cwts.}$, as taken in the foregoing Table 1 for the quantity of carbon transferred from the condition of carbonic acid to that of carbonic oxide per ton of pig-iron. 
In like manner where lime was employed, containing 0.22 cwt. of carbon as carbonic acid unexpelled, the total quantity of carbonic acid produced in the furnace will be as follows :--

Carbon for reduction $\quad 6 \cdot 04 \times 22 \div 6=22 \cdot 15 \mathrm{cwts}$. of carbonic acid.

Carbon of flux . . $0.22 \times 22 \div 6=0.81$ cwt. of carbonic acid.

Total Cirbon . $\quad \overline{6 \cdot 26} \times 22 \div 6=\overline{22 \cdot 96} \mathrm{cwts}$ of carbonic acid.

If these 6.26 cwts. of carbon all appeared as carbonic acid in the escaping gases, the balance should pass away as carbonic oxide, namely $17 \cdot 06-6 \cdot 26=10 \cdot 80 \times 14 \div 6=25 \cdot 20 \mathrm{cwts}$. of carbonic oxide. Whence the perfect ratio of carbonic acid to carbonic oxide would have been $22 \cdot 96 \div 25 \cdot 20=0 \cdot 911$; whereas in actual work it fell to 0.535 , showing that the carbon transferred from the condition of carbonic acid to that of carbonic oxide amounted to $1.93 \mathrm{cwt}$. per ton of pig-iron.

It is most important to notice the sources of these two different transfers. Obviously it might fairly be supposed that there should have been a difference between them of $1.52-0.22=1.30 \mathrm{cwt}$.; so that the transfer of $2.44 \mathrm{cwts}$. in the limestone furnace should have been lowered to $1.14 \mathrm{cwt}$. in the lime furnace; whereas it appears at 1.93 cwt. Let us therefore examine how the 2.44 and 1.93 are made up in the respective cases of working with limestone and with lime.

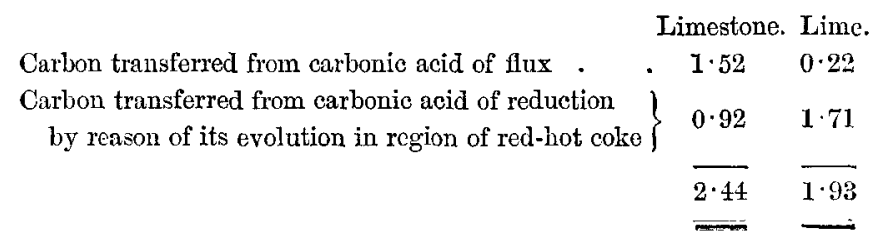

With limestone the transfer of 2.44 cwts. of carbon is made up of the $1.52 \mathrm{cwt}$. of carbon from the carbonic acid of the flux, and only 0.92 cwt. from the carbonic acid of reduction; while with lime the transfer of $1.93 \mathrm{cwt}$. is made up of the $0.22 \mathrm{cwt}$. from the carbonic acid of the flux, and no less than $1.71 \mathrm{cwt}$. from the carbonic acid of reduction, being nearly twice as much from the carbonic acid of reduction when working with lime as when working with limestone. 
The use of lime has therefore failed to accomplish some of the benefit which the anthor ventured to hope and predict in January 1883 : thus showing that its employment is not an unmixed good. For through a combination of causes the reduction of ironstone when working with lime as flux has been less effective to the extent of $1.71-0.92=0.79 \mathrm{cwt}$. of carbon per ton of pig-iron, equivalent in the present comparison to a loss of $0.79 \times 1.26+0.79=$ 1.79 cwt. of carbon per ton of pig-iron. To make this point clearer, in the case of working on limestone the proportion of ironstone reduced in the cooler regions of the furnace out of contact with red-hot coke was $50 \cdot 13 \times 5 \cdot 12 \div 6 \cdot 04=42.49$ cwts. per ton of pig-iron; whilst there passed down into the red-hot zone for reduction there $50.13 \times 0.92 \div 6.04=7 \cdot 64 \mathrm{cwts}$. For working on lime the corresponding figures are $50.00 \times 4 \cdot 33 \div 6 \cdot 04=35 \cdot 84$ cwts., and $50.00 \times 1.71 \div 6.04=14.16 \mathrm{cwts}$. In neither of these cases does the dreaded proportion appear of 1 volume of carbonic acid to 2 volumes of carbonic oxide; for from the analysis given in Table 1 it is seen that the proportion when working on limestone was only $9 \cdot 25: 30 \cdot 89$ or $1: 3 \frac{1}{3}$, and when working on lime $9 \cdot 79: 28 \cdot 95$ or $1: 3$ nearly. The consideration of these volumetric proportions may therefore be dismissed as inoperative in the present instances.

What then are the causes of the diminution in the weight of carbonic acid of reduction-that is, of the increase in the weight of carbon transferred from the carbonic acid of reduction into the condition of carbonic oxide-despite the removal of 85 per cent. of the carbonic acid from the lime used as flux ? The causes of this disappointment when working on lime are twofold:-

Firstly, as intimated at the outset (page 592), when limestone is used, all or nearly all the carbonic acid it contains is necessarily converted into carbonic oxide, thus increasing and prolonging the activity of the reducing zone in a cooler region, while at the same time this cooler region is extended downwards by the absorption of the heat due to the unburning of the carbonic acid to carbonic oxide; thus protracting or prolonging the period of reduction of 
the ironstone within the extended reducing region: so that the employment of limestone is not an unmixed evil.

Secondly, when lime is used, the weight of carbonic oxide is comparatively diminished, the cool reducing zone is curtailed in its depth, and the total volume of gases is greatly diminished, by reason of the greatly diminished consumption of fuel in the furnace, due to the very economy secured by the previous expulsion of carbonic acid from the flux. When working on lime, the ironstone undergoing the process of reduction is thus subjected both to the passage of a smaller quantity of reducing gas over it, and to that passage during a shorter period of time before entering the red-hot zone, which zone by the use of lime has been raised somewhat higher in the furnace.

To reduce the above conditions to actual figures, we have when working on limestone, according to Table 2, a weight of 146.23 cwts. of gas per ton of pig-iron, which are passing over the materials entering the furnace, and of which $39 \cdot 64 \mathrm{cwts}$. consist of carbonic oxide, or 27 per cent. of the total. When working on lime, we have only $113 \cdot 10 \mathrm{cwts}$. of gas per ton of pig-iron, passing over the ironstone as it enters the furnace, of which only $29 \cdot 70$ cwts. are carbonic oxide, or 26 per cent. of the total. It will thus be seen that there is only a trifling difference in the percentage of carbonic oxide in the total gases as they leave the furnace: so that, ir explanation of the diminished reduction of ironstone in the cooler reducing regions of the furnace when working 'on lime, there remains the important fact that the materials from which a ton of iron is produced are exposed to the influence of only $29 \cdot 70 \mathrm{cwts}$. of carbonic oxide when lime is employed as flux, instead of to that of $39.64 \mathrm{cwts}$. when limestone is employed : a proportion of about 3 to 4 , or 25 per cent. less carbonic oxide when working on lime.

But whilst disappointment has to be confessed to the extent indicated, there are one or two conclusions to be drawn from the above comparisons, which will well reward further consideration.

The air required for consuming the coke per ton of pig-iron is seen from Table 1 to have been in the case of limestone 114.05 cwts., and with lime only $87 \cdot 69 \mathrm{cwts}$, showing a direct economy of 
26.36 cwts. of air, or 23 per cent.; whilst with the same pressure of blast and the same tuyere area the furnace when working on lime turned out 2,453 tons of iron per month against 2,141 tons per month when working on limestone, Table 2 . It is in consequence of this increase in the output that the item of sundries in the statement of expenditure of fuel (Table 2) has been reduced from $3 \cdot 78$ with limestone to $3 \cdot 30$ with lime. It is not generally known how far the constancy of the loss by radiation and by tuyerewater \&c. affects the consumption of fuel by reason of increased output; within certain limits this explains the fact that extra driving may be and is accompanied by reduction of fuel consumed to make a ton of iron.

Before passing away from the subject of the smaller quantity of air required to make a ton of iron when lime is employed as flux, it will be proper here to refer to M. Grüner's claim that he was the first to show how, from a knowledge of the quantity of coke consumed and the ratio of carbonic acid to carbonic oxide, the weight of air needed could be accurately ascertained. This in itself was a great stride towards the correct understanding of the phenomena of blast-furnace practice; and the writer has never seen his claim challenged. That method is absolutely correct, and must in any future calculations supersede all other rough and ready methods hitherto in vogue for determining the quantity of air needed.

Attention may here be drawn to two errors into which the author fell in the comparative results given in his paper in 1883. Firstly, he omitted to allow for the carbon needed to melt the ton of pigiron on which the calculations were based, and was under a misapprehension at the time that it was included elsewhere. Secondly, he also assumed that the total loss of carbon in the transfer of a unit of carbon from the condition of carbonic acid to that of carbonic oxide was $3 \cdot 26$ times the amount of that unit; whereas it should have been $2 \cdot 26$ times:-namely 1 unit absorbed by the carbonic acid in the red-hot region, and 1.26 unit needed to be burnt into carbonic oxide at the tuyeres in order to meet the cooling effect of that absorption. In the present comparison of 
limestone and lime an allowance of $0.90 \mathrm{cwt}$. has been made for melting the $20 \mathrm{cwts}$. of pig-iron, notwithstanding that M. Grüner adopts Sir Lowthian Bell's figure of 330 calories, which is equivalent to $330 \times 20 \div 2,473=2 \cdot 67 \mathrm{cwts}$. of carbon burnt to carbonic oxide for melting a ton of pig-iron; whereas in practice a good cupola can melt a ton of pig-iron with less than 1 cwt. of coke. The author strongly suspects some error in the determination of heat contained in pig-iron running from a blast-furnace or cupola; and is glad to learn that M. Grüner investigated the matter further after accepting Sir L. Bell's suggested average of 330 calories. In an admirable pamphlet by M. J. Wolters, written in 1876 on the lines of M. Grüner's work, and called "Études sur Ia fabrication de la fonte blanche pour fer fort au moyen des minettes ou minerais oolithiques du Luxembourg," he refers to M. Grüner's researches on the fusion of white iron, and gives the reduced figure of 265 calories, equivalent to $2 \cdot 14$ cwts. of carbon per ton of pigiron; but according to actual cupola practice this is still far too high, and the author has always pictured to himself that the blast-furnace must necessarily surpass the average cupola in economy of melting iron: so that he trusts the figure he has adopted of 0.90 ewt. of carbon burnt to carbonic oxide per ton of pig-iron will not be found far from the truth. 


\section{Discussion.}

Sir Lowtmian Beli, Bart., Past-President, said this was not the first time that he and the anthor of the paper just read had not altogether agreed in their views with regard to blast-furnace work. At the outset he wished to thank him for the very kind expressions he had used with regard to himself in the opening page of his paper. He would also take the opportunity of expressing his own appreciation, and he was sure that of the Members generally, of the very great service that their President had rendered, not only by his elaborate experiments on the working of blast-furnaces, but still more by the candour with which he had communicated to the world the results of his observations.

There were very few who knew better than Mr. Cochrane the great difficulty of forming an opinion with regard to the action of a blast-furnace by the analysis of the escaping gases. The operations were conducted on so large a scale, and the quantity of the material dealt with was so enormous, that it was most difficult for an investigator to satisfy himself that at any particular time he was not dealing with a peculiar and it might be an entirely abnormal condition of the furnace, instead of with an average of its performance. This difficulty he had himself endeavoured to aroid by always devoting a considerable space of time for taking the samples of gas which he wished to analyse, something like two hours being usually devoted to collecting the specimen, during which he fancied that there was a reasonable chance of getting something like an average expression of the conduct of the furnace.

From the paper now read he supposed there could be no doubt that the presence of carbonic acid, in some quantity or other of which he did not find exact information given by the author, was regarded by him, as it had long been by himself, as a very important element in judging of the manner in which the furnace was performing its work. But the question was, to what extent could that carbonic acid be expected to be found in the gases escaping from the blast-furnace: in other words, was there a ratio of carbonic acid to carbonic oxide which could not be exceeded? In the first 
(Sir Lowthian Bell, Bart.)

page of the paper he found himself quoted as having said that there was an absolute limit to the action of converting carbonic oxide in a blast-furnace into carbonic acid; and the late M. Grüner was represented as having too readily accepted that heretical doctrine. Now it was perfectly true that he had himself maintained that there was such an absolute limit; but he had never asserted what that absolute limit was, because he did not as yet know it by actual experiment; he had himself performed no experiments, and he thought it would be difficult to perform any experiments, on a blast-furnace scale, in order to ascertain what that particular limit exactly, was. At the same time he did not recede one iota from the strong belief which he had often expressed, and which he now expressed again, that in all probability the ratio would never be found to exceed one volume of carbonic acid to two volumes of carbonic oxide. In saying this he did not pretend for a moment that it was impossible by means of peroxide of iron to convert carbonic oxide entirely into carbonic acid; indeed he had himself proved the contrary. That possibility was a fact which he should think was known to every chemist; but what were the conditions to be observed in order to effect this entire conversion? There must be a great excess of peroxide of iron; for it was easy to suppose that a molecule of iron could retain its combined oxygen with varying degrees of energy according to the quantity with which the metal was united. If so, then the first portions of oxygen which were removed from the peroxide of iron might be far more easily separated from the iron than wero the last. Then upon what ground did he himself maintain that there was a limit to the quantity of carbonic acid which might be found in the gases escaping from a blast-furnace in comparison with the quantity of carbonic oxide? The author had spoken of his having assigned an arbitrary limit to this ratio; and he should therefore like to recall an experiment which he had performed. He took a quantity of peroxide of iron, heated it red hot, and passed over it a mixture of carbonic oxide and carbonic acid in equal volumes. This mixture of gases at once began to detach the first portions of the oxygen; but as soon as 33 per cent. of the oxygen had been separated from the oxide, thereby reducing 
it to protoxide of iron, the mixture of carbonic oxide and carbonic acid of the above composition became entirely inert : that is, it could separate no more oxygen from the iron than the 33 per cent. of that contained in the peroxide. Was it rash then to state that at all events there was a probable limit to the ratio in which carbonic oxide and carbonic acid could exist together in the furnace gases, beyond which the mixture would lose its reducing power? But lest there might possibly be any demur to such a conclusion, the experiment just mentioned had been followed up by another. Instead of taking peroxide of iron, he had taken what was known as spongy iron, that is, oxide of iron which had been exposed in a heated tube to a current of hydrogen until no more water was formed: an indisputable chemical proof that the oxide of iron originally placed in the tube was now perfectly pure metallic iron in its spongy form. Over the pure iron so obtained, and heated in the manner pursued with the peroxide, a current was passed of carbonic oxide and carbonic acid, also in equal volumes, this proportion being the same as that which had sufficed to rob the peroxide of iron of 33 per cent. of its oxygen; and what now took place? The iron instantly began to decompose the carbonic acid, and went on absorbing oxygen from this constituent of the mixture of gases until it had reached the condition of protoxide of iron, that is, until it had reached the same condition at which the peroxide had left off losing oxygen. From these two facts, taken either separately or in conjunction, he did not know what other conclusion could be come to than that in the blastfurnace, with a mixture of those two gases and with either oxide of iron or metallic iron, there was a limit of a most indisputable character to the ratio of the two gases forming a neutral mixture. It was of course to be remembered that the ratio between these two gases was greatly influenced by temperature: more heat was required in order to enable carbonic acid to obtain the mastery as it were over carbonic oxide; for when the temperature was lowered, the mastery of carbonic oxide began to prevail, and the peroxide of iron could be reduced to a much greater extent than it could be at the higher temperature. Hence at the top of a blast-furnace properly constructed and properly conducted there was no difficulty, at a 
(Sir Lowthian Bell, Bart.)

temperature say of $300^{\circ}$ to $400^{\circ}$ centig. or $570^{\circ}$ to $750^{\circ} \mathrm{Fahr}$., in charging the escaping gases with carbonic acid to the extent of the limit he had mentioned, namely one volume of carbonic acid to something above two of carbonic oxide, reduction of the ore going on up to that point. The present question he presumed was whether the oxidation of the carbonic oxide could be carried further than the extent just mentioned. All he could say was that in the escaping gases of a blast-furnace, and of course at the temperature prevailing in that portion of the furnace, he had left minute specimens of Cleveland ironstone for 96 hours; and at the end of that time he had found only a very slight diminution of the oxygen in the ore. That is to say that an enormous current of heated blast-furnace gases, passing over small quantities of ironstone, was unable in 96 hours to extract from it more than 5 per cent. of its combined oxygen. Was it therefore extravagant to say that, when the gases in the] ratio of one volume to two, or thereabouts, were found to be so inert, it looked very much as if there must be a limit to the ratio? None the less in the case of a blast-furnace, as he had already said, it was extremely difficult to get at what was the precise limit. Of course it was a comparatively easy thing to reduce iron ores in a laboratory, and he had done it over and over again with all proportions of the two gases; and there effects were obtained which might easily deceive and mislead from the cause he had mentioned, namely that at first, when there was a comparatively large quantity of oxygen present in combination with iron, it was not difficult to abstract a portion of it. The author had spoken of the late Professor Grüner as corroborating Sir Lowthian Bell's viows in his "Études sur les Hauts-Fourneaux," a work which in point of fact, as mentioned in the paper, was in reality an examination of the experiments which he had himself performed and had described elsewhere. Mr. Cochrane agreed in page 590 of his paper with Professor Grüner's opinion that the ratio of carbonic acid to carbonic oxide was the keynote of the position; but then he proceeded to say that it had needed years of practical experience, in the light of Sir Lowthian Bell's analytical experiments and of M. Grüner's inferences, to solve the problem. 
Now if he was correct in his apprehension of the paper, the author's meaning must be that there was no limit to the ratio of those two gases.

The President interposed that there was a limit, and he had adopted it in the paper as Professor Grüner's limit (page 589); he had in each case, with limestone and with lime, defined (pages 599 and 600) the limit of carbonic acid for the perfect working of the blast-furnace under the circumstances detailed in Tables 1 and 2.

Sir Lowthran Beic imagined then that the author meant the limit of carbonic acid had been understated by himself, and that this gas might be considerably higher than half the volume of the carbonic oxide. Therefore, if the author dissented from the other interpretation of his meaning, it must be that the author expected a higher limit, that is, a greater proportion of carbonic acid. Was this the correct inference to draw from the paper?

The President considered that the limit might be higher under circumstances different from those of Sir Lowthian Bell's experiments now described.

Sir Lowthian BeLL was of opinion that no ordinary difference of circumstances would affect the limit to the ratio of the two gases, and was willing to concede the choice of circumstances in any form. In justification of his own view he had already stated that, when the gases were leaving a large blast-furnace with their reducing capacity satisfied, in no one of the many analyses which he had made, and these at many different furnaces, had he ever found more than an average of one volume of carbonic acid to two of carbonic oxide. If this statement were contested in the present paper, it would certainly seem that an extraordinary course was taken for confuting it. For what were the statements made in the paper itself in support of the author's views? One volume of carbonic acid to two of carbonic oxide meant that by weight the mixed carbon gases contained 33 per cent. of their entire carbon in 
(Sir Lowthian Bell, Bart.)

the form of carbonic acid. In the paper the author gave his own results; and what were they? In the furnace using raw limestone the analysis of the escaping gases (page 595) showed that only 23 per cent. of their entire carbon was contained in the carbonic acid, equal therefore to 1 vol. of carbonic acid to $3 \cdot 34$ vols. of carbonic oxide : so that in point of fact the proportion of carbonic acid was much less than he had himself almost always found in his experience with large furnaces. It was true that the author said the furnace using raw limestone was working under disadvantageous circumstances by the use of this mineral; and he proposed to remove the defect by calcining the limestono beforehand, and using lime instead; but even then the analysis showed only 25 per cent. by weight as the proportion of carbon contained in the carbonic acid of the gases, or 1 vol. of carbonic acid to 2.95 vols. of carbonic oxide. It would therefore be seen that the limit which he had himself attained for the ratio of carbonic acid to carbonic oxide in the escaping gases was much higher than was shown by the author's practice to be possible in what he appeared to think was the perfection of blast-furnace working.

With regard to the retention of carbonic acid in the gases of a blast-furnace, he had pointed out on previous occasions that the probable result of introducing a very hot blast into the furnace might be to facilitate the action of the coke upon carbonic acid. Referring to the accompanying Table 3 , it would be seen that in experiment $\mathbf{C}$ the temperature of the blast admitted into the furnace of 80 feet height was $485^{\circ}$ centig.; the quantity of heat emitted by one unit of coke (not pure carbon) burnt to carbonic oxide was 2,018 calories, and by the conversion of a certain portion of this carbonic oxide into carbonic acid there was evolved 1,636 calories; and then there was conveyed into the furnace by the blast 534 calories, making a total of 4,188. In experiment $D$ made on the same furnace, but with the blast hented to $695^{\circ}$ centig., it would be seen that the total heat erolved was increased to 4,240 calories; but what he would call attention to was this: that, while the quantity of heat which entered the furnace with the blast had risen from 534 to 732 calories, the quantity of heat developed by the carbonic acid 
TABLE 3.-Heat (calories centigrade) supplied into Blast-Furnace per unit of Cole burnt.

\begin{tabular}{|c|c|c|c|c|c|c|}
\hline Experiment . & $\mathbf{A}$ & $\mathbf{B}$ & $\mathrm{C}$ & $\mathbf{D}$ & \multicolumn{2}{|c|}{ Ormesby } \\
\hline Height of Furnace . feet & 48 & 48 & 80 & 80 & 76 & 76 \\
\hline $\left.\begin{array}{c}\text { Temperature } \\
\text { of Blast }\end{array}\right\} \quad$ centigrade & $0^{\circ}$ & $485^{\circ}$ & $485^{\circ}$ & $695^{\circ}$ & $807^{\circ}$ & $765^{\circ}$ \\
\hline Calories. & Cal. & Cal. & Cal. & Cal. & Cal. & Cal. \\
\hline Per unit of Coke burnt to CO & 2,078 & 2,028 & 2,018 & 2,045 & 2,029 & $2, \mathrm{I} 20$ \\
\hline $\begin{array}{l}\text { From portion of } \mathrm{CO} \text { burnt } \\
\text { to } \mathrm{CO}_{2}\end{array}$ & 560 & 1,059 & 1,636 & $x, 4^{6} 3$ & $I, 232$ & r, 243 \\
\hline Total calories from Coke . & 2,638 & 3,087 & 3,654 & 3,508 & $3,26 \mathrm{I}$ & 3,363 \\
\hline Calories in Blast & $\circ$ & 508 & 534 & 732 & 924 & 816 \\
\hline $\begin{array}{c}\text { Total calories supplied into } \\
\text { Furnace }\end{array}$ & 2,638 & 3,595 & 4,188 & 4,240 & 4,185 & 4,179 \\
\hline
\end{tabular}

had fallen from 1,636 to 1,463 calories. So that in fact from $a$ purely calorific point of view there had been no advantage whatever from the hotter blast: unless indeed the greater heat brought in by the blast had been obtained by combustion of the waste gases, in which case of course there was a distinct advantage of a purely commercial character. Neither from a calorific nor from a commercial point of view however was there anything like the advantage that had been predicted by those who had first advocated the use of highly heated air; but there was still quite enough to justify its use. Mr. Cochrane's figures in his present Tables $I$ and 2 also gave exactly the same result; as compared with experiment $\mathrm{C}$ in Table 3 , there was a great falling off in the heat evolved from carbonic acid with a hotter blast, as seen from the last two columns in Table 3, which showed the heat evolution per unit of coke in the two cases given in the paper. There was however a marked advantage in the use of highly heated air, namely the diminished volume of escaping gases, as would be seen in Table 4.

With regard to the great question of working on lime instead of on limestone, it was true that when limestone was thrown into a 
(Sir Lowthian Bell, Bart.)

blast-furnace it retained its carbonic acid so strongly that, as the author had said in page 592, it only parted with it on arriving at a portion of the furnace where the heat was such as also to decompose the carbonic acid given off by the limestone. Of course that was an inconvenience, and he quite admitted with the author that it would be a very good thing if by working on lime it could be aroided : but the substitution of lime for limestone produced no such result. Because, if a quantity of caustic lime, that is lime from which carbonic acid had been expelled, were heated to a moderate red heat-in fact the action began at a much lower heat than this-it absorbed carbonic acid which at a higher temperature was expelled. He had therefore no doubt whatever in his own mind - he had not been able to prove it, because it was not easy to do in a blast-furnace, but he had proved it over and over again in the laboratory-that caustic lime, at temperatures prevailing in the upper regions of the furnace, absorbed carbonic acid with great rapidity; and he accordingly believed that any advantage gained from its previous calcination ended in its re-absorbing carbonic acid when charged into the blast-furnace. Such carbonic acid, he need scarcely say, would be given off in the hotter; zone just the same, and with the same results, as if the carbonate of lime had been in the form of limestone. From the paper it appeared that Mr. Cochrane had found lime of great benefit. But its use had been begun by Mr. Windsor Richards in a blast-furnace of 80 or 90 feet height at Eston; and he should like to hear what he had to say about the practice. He did not know whether at the time of Mr. Richards leaving Eston it had already been discontinued; but it certainly was not being continued at present. Recognising that there was a certain amount of advantage gained in the old furnaces of 48 feet height by calcining the limestone beforehand, he had himself ascertained what was the effect of using lime in a large furnace; and he had then found the result not favourable to the continuance of the plan in large furnaces such as those now used. in Cleveland. Messre. Samuelson also had begun to use calcined lime, and he understood that they still used it for some purposes; but for smelting Cleveland ironstone they had entirely abandoned 
TABLE 4.-Appropriation of Heat in Blast-Furnace per ton of Pig-Iron, in Calories (centigrade) and equivalent cuts. of Coke.

See foot-note pase 614 .

\begin{tabular}{|c|c|c|c|c|c|c|c|c|}
\hline \multirow{2}{*}{$\begin{array}{l}\text { Experiment } \\
\text { Height of Furnace, and Temp. of Blast (centig) } \\
\text { Calories (centig.), and equivalent cwts. of Coke }\end{array}$} & \multicolumn{2}{|c|}{$\frac{\mathrm{A}}{48 \text { feet, and } 0^{\circ}}$} & \multicolumn{2}{|c|}{$\frac{\mathrm{B}}{48 \text { feet, and } 485^{\circ}}$} & \multicolumn{2}{|c|}{80 feet, and $485^{\circ}$} & \multicolumn{2}{|c|}{$\begin{array}{c}\mathbf{D} \\
80 \text { feet, and } 695^{\circ}\end{array}$} \\
\hline & Calories. & Coke. & Calories. & Coke. & Calories. & Coke. & Calories. & Coke. \\
\hline $\begin{array}{l}\text { Constants. } \\
\text { Reduction of } \mathrm{Fe}_{2} \mathrm{O}_{3} \text { in ore } \\
\text { ", Metalloids in pig-iron } \\
\text { Dissociation of } \mathrm{CO} \quad\left(2 \mathrm{CO}=\mathrm{C}+\mathrm{CO}_{2}\right) \\
\text { Fusion of Pig-Iron }\end{array}$ & $\begin{array}{r}33,108 \\
4,174 \\
\mathbf{1}, 440 \\
6,600\end{array}$ & $\begin{array}{r}\text { cwts. } \\
12 \cdot 550 \\
1 \cdot 582 \\
0 \cdot 546 \\
2 \cdot 501\end{array}$ & $\begin{array}{r}33,108 \\
4,174 \\
1,440 \\
6,600\end{array}$ & $\begin{array}{l}\text { cwts. } \\
9 \cdot 209 \\
1 \cdot 161 \\
0 \cdot 400 \\
1 \cdot 836\end{array}$ & $\begin{array}{r}33,108 \\
4,174 \\
1,440 \\
6,600\end{array}$ & $\begin{array}{l}\text { cwts. } \\
7 \cdot 905 \\
0 \cdot 996 \\
0 \cdot 344 \\
\mathbf{1} \cdot 576\end{array}$ & $\begin{array}{r}33,108 \\
4,174 \\
1,440 \\
6,600\end{array}$ & $\begin{array}{l}\text { cwts. } \\
7 \cdot 808 \\
0 \cdot 984 \\
0 \cdot 340 \\
1 \cdot 557\end{array}$ \\
\hline Constants per ton of pig-iron & 45,322 & $17 \cdot 179$ & 45,322 & $12 \cdot 606$ & 45,322 & $10 \cdot 821$ & 45,322 & $10 \cdot 689$ \\
\hline $\begin{array}{l}\text { Variables. } \\
\text { Evaporation of Water in Coke } \\
\text { Decomposition of Moisture in Blast } \\
\text { Expulsion of } \mathrm{CO}_{2} \text { from Limestone } \\
\text { Reduction " " " " } \\
\text { Fusion of Slag " } \\
\text { Carried off in Fscaping Gases } \\
\quad \text { " "Tuyere Water, Radiation \&c. }\end{array}$ & $\begin{array}{r}630 \\
5,420 \\
6,660 \\
6,912 \\
18,590 \\
29,482 \\
5,694\end{array}$ & $\begin{array}{r}0 \cdot 239 \\
2 \cdot 055 \\
2 \cdot 526 \\
2 \cdot 620 \\
7 \cdot 045 \\
11 \cdot 178 \\
2 \cdot 158\end{array}$ & $\begin{array}{r}411 \\
3,348 \\
5,920 \\
6,144 \\
17,325 \\
18,486 \\
7, \text { OI } 1\end{array}$ & $\begin{array}{l}0 \cdot 114 \\
0 \cdot 931 \\
1 \cdot 647 \\
1 \cdot 709 \\
4 \cdot 819 \\
5 \cdot 144 \\
1 \cdot 950\end{array}$ & $\begin{array}{r}312 \\
2,720 \\
5,054 \\
5,248 \\
16,720 \\
11,043 \\
7,057\end{array}$ & $\begin{array}{l}0 \cdot 074 \\
0 \cdot 649 \\
1 \cdot 207 \\
1 \cdot 254 \\
3 \cdot 993 \\
2 \cdot 636 \\
1 \cdot 686\end{array}$ & $\begin{array}{r}298 \\
2,408 \\
4,070 \\
4,099 \\
15,565 \\
8,906 \\
9,389\end{array}$ & $\begin{array}{l}0 \cdot 070 \\
0 \cdot 568 \\
0 \cdot 961 \\
0 \cdot 962 \\
3 \cdot 673 \\
2 \cdot 101 \\
2 \cdot 216\end{array}$ \\
\hline Variables per ton of pig-iron & 73,388 & $27 \cdot 821$ & 58,645 & $16 \cdot 314$ & 48,154 & $11 \cdot 499$ & 44,735 & $10 \cdot 551$ \\
\hline Sum of Constants and Variables & 118,710 & $45 \cdot 000$ & 103,967 & $28 \cdot 920$ & 93,476 & $22 \cdot 320$ & 90,057 & $21 \cdot 240$ \\
\hline $\begin{array}{l}\text { Weight of Blast per ton of pig-iron } \\
\text { Weight of Escaping Gascs } \\
\text { Weight of Slag . }\end{array}$ & & $\begin{array}{r}228 \\
285 \\
34 \\
18\end{array}$ & & $\begin{array}{r}128 \\
170 \\
31 \\
16\end{array}$ & & $\begin{array}{r}103 \\
138 \\
29 \\
12\end{array}$ & & $\begin{array}{r}94 \\
126 \\
28 \\
11\end{array}$ \\
\hline
\end{tabular}


(Sir Lowthian Bell, Bart.)

it. As resulting from a condition of things which he himself was quite certain did not in reality exist, an economy of 3.75 cwts. of carbon per ton of pig-iron had been put down in the paper (page 598) as obtained by working on lime. Assuming however that caustic lime did not re-absorb carbonic acid, and consequently had none to give off in the hot zone where its presence was hurtful, he apprehended the saving of $3 \cdot 75 \mathrm{cwts}$. of carbon had been overestimated in the paper. In the accompanying Table 4 was shown the heat absorbed in the various stages in smelting iron ore in different sized blast-furnaces. Taking the last instance $D$ of a furnace 80 feet high, using about the same quantity of limestone as was consumed at Ormesby, it would be seen that the number of calories absorbed in expelling the carbonic acid from the limestone was 4,070 per ton of pig-iron, and the heat absorbed in reducing the carbonic acid from the limestone to carbonic oxide was 4,099 calories; making together 8,169 calories. Now the coke burnt in furnace $D$ per ton of pig-iron had been $21 \cdot 24$ ewts., and the number of calories represented by that consumption had been 90,057 . Hence the foregoing 8,169 calories would represent in the same furnace only 1.92 cwt. of coke. It was therefore clear that in the furnace it would be found impossible to save $3.75 \mathrm{cwts}$. of carbon per ton

Foot-note to Table 4, page 613.-.The factors from which the heat absorbed is estimated in Table 4 are taken from the average determinations of the best authorities on the subject, and occasionally verified, where necessary, in the laboratory of the Clarence Iron Works. To ascertain the equivalents in coke, the calories so obtained are divided by the heat obtained from burning each unit of coke. Thus in furnace $D, 90,057 \div 4,240=21 \cdot 24$ cwts. of coke, made up of the items given under this head. If, as contended by the author, the divisor should be 2,473 calories (carbon burnt to carbonic oxide), the coke consumed for any object will be correspondingly increased; and thus $3.75 \mathrm{cwts}$. have been obtained in the paper, instead of $1.92 \mathrm{cwts.}$ as stated in Table 4. That which is contended for in regard to this one item is applicable to all; therefore 90,057 $\div 2,473=36.42$ cwts. of carbon ; and allowing 10 per cent. for ash in the coke, $36.42 \times 100 \div 90=40.47 \mathrm{cwts}$. of coke, the quantity used being $21 \cdot 24 \mathrm{cwts}$. of coke. In support of the general correctness of the figures made use of in Table 4 may be adduced the fact that the calculation of the heat evolved in the case of furnace $\mathbf{D}$ was 89,838 calories against 90,057 calories appropriated. 
of pig-iron by merely calcining the lime, for the simple reason that it did not take at the outside so much as $2 \mathrm{cwts}$. of coke to effect both the expulsion of the carbonic acid from the limestone and its reduction into carbonic oxide. He accordingly began to consider for himself to what the alleged economy of 3.75 cwts. of coke was due. The limestone furnace was put down in page 595 as consuning $23.28 \mathrm{cwts.}$ of coke per ton of pig-iron. But in the author's paper in 1883 the consumption of fuel in May 1882 in the same furnace using limestone had been given as 21.45 cwts. of coke per ton of pig-iron (Proceedings 1883, page 119). What had happened to that furnace since 1882? It was still working on limestone as it did then; but instead of still using only 21.45 cwts. of coke, it was now using 23.28 cwts. If so, why not compare its former instead of its present rate of consumptionthat is $21.45 \mathrm{cwts}$. instead of $23.28 \mathrm{cwts}$. - with the $19.49 \mathrm{cwts}$. now ascribed in Table 1 to the use of lime?

There was another matter that he wished to point out. The anthor looked for the day (page 593, line 19) -and he was afraid be would have to look for it for a very long time-when a perfect reduction of oxide of iron would be accomplished in the cooler region of the furnace, that is, at the top. He said this because if, instead of charging ironstone into the furnace, metallic iron-spongy iron-were so treated, and if nothing but pure carbonic oxide were present there: that iron he believed would combine with something like 20 per cent. of the oxygen originally contained in peroxide of iron. The explanation of this action was probably due to the fact that, when carbonic oxide was passed over either oxide of iron or even over metallic iron, at a moderate elevation of temperature, there was a decomposition of the carbonic oxide, carbon being precipitated and carbonic acid formed. Essentially the action was represented by the formula $2 \mathrm{CO}=\mathrm{C}+\mathrm{CO}_{2}$; but in reality it was of a much more complicated character. It was of importance however to mention that accompanying this reaction some iron was oxidised, or some of the oxide of iron escaped reduction. If it were urged that what happened in the laboratory might not take place in the blast-furnace, he would refer to the accompanying Table 5 , in 
(Sir Lowthian Bell, Bart.)

\section{TABLE 5.}

Weight of Oxygen and Carbon in Blast-Furnace Gases

$$
\text { per ton of Pig-Tron, }
$$

at different depths below top of minerals in furnace.

\begin{tabular}{|c|c|c|c|c|c|c|c|c|}
\hline \multirow{2}{*}{$\begin{array}{c}\text { Depth } \\
\text { below } \\
\text { top of } \\
\text { minerals. }\end{array}$} & \multicolumn{2}{|c|}{ No. 1 furnace. } & \multicolumn{2}{|c|}{ No. 2 furnace. } & \multicolumn{2}{|c|}{ No. 3 furnace. } & \multicolumn{2}{|c|}{ No. 4 furnace. } \\
\hline & Oxygen. & Carbon. & Oxygen. & Carbon. & Oxygen. & Carbon & Oxygen. & Carbon. \\
\hline Feet. & Ton. & Ton. & Ton. & 'Ton. & Ton. & Ton. & 'Ton. & Ton. \\
\hline 0 & $I \cdot 843$ & $1 \cdot 101$ & $I \cdot 843$ & $1 \cdot 104$ & $I \cdot 670$ & $1 \cdot 048$ & $I \cdot 670$ & $1 \cdot 0 \pm 8$ \\
\hline $8 \frac{1}{2}$ & $I=250$ & 0.864 & $\ldots$ & $\ldots$ & $I \cdot 309$ & 0.926 & $1 \cdot 271$ & 0.897 \\
\hline 18 & $I \cdot 235$ & $0 \cdot 816$ & 1.410 & 0.914 & $I \cdot 206$ & 0.907 & $I \cdot 224$ & 0.898 \\
\hline 31 & $I \cdot 234$ & 0.871 & $\mathbf{I} \cdot 482$ & $1 \cdot 046$ & $I \cdot 312$ & 0.918 & $I \cdot 300$ & 0.917 \\
\hline $44 \frac{\pi}{2}$ & $x-236$ & 0.904 & $I \cdot 190$ & 0.894 & $I .256$ & 0.946 & $\ldots$ & ... \\
\hline 57 & $I \cdot 207$ & 0.899 & $1 \cdot 207$ & 0.887 & $I \cdot 253$ & 0.931 & $I \cdot 26 I$ & 0.926 \\
\hline $62 \frac{1}{2}$ & $I \cdot 137$ & $0 \cdot 890$ & $I \cdot 255$ & $\ldots$ & $I \cdot 253$ & 0.939 & $1 \cdot 285$ & 0.977 \\
\hline 68 & $I \cdot 34^{8}$ & 0.967 & $\mathrm{I} \cdot 366$ & $0 \cdot 927$ & $x \cdot 37^{8}$ & $1 \cdot 013$ & I. 387 & $1 \cdot 021$ \\
\hline
\end{tabular}

A depth of 8 feet immediately below the charging plates is occupied by charging apparatus.

Furnaces No. 3 and No. 4 were using partially calcined limestone; hence the deficiency of oxygen and carbon until the lower depths are reached.

which were given the weights of oxygen and of carbon in the gases at different depths below the top of the charge in four furnaces, per ton of pig-iron produced. Comparing in No. 1 furnace the respective weights between $62 \frac{1}{2}$ and 68 feet depth, it would be seen that the weight of oxygen in the gases increased from $1 \cdot 137$ to $1 \cdot 348$ ton near the tuyeres, at the same time that the carbon increased from 0.890 to 0.967 ton per ton of pig-iron. How were these additional quantities to be accounted for? In his opinion they were due to oxygen being absorbed from carbonic oxide, either by metallic iron or by some suboxide of iron, through the action which he had just explained. Carbon had been precipitated from the carbonic oxide simultaneously with a retention or absorption of oxygen by the iron. The oxygen and carbon thus communicated to the ore were retained 
until they reached the tuyeres, where both were returned to the gases. It would be observed that in each of the examples given in Table 5 the increase of oxygen and carbon in the gases was found to take place. In page 594 of the paper the slight excess of carbonic acid discovered in the escaping gases had been spoken of as proceeding from a trifling wave of carbonic acid displaced from the surface of the limestone; but that view he thought was a mistaken one, for he believed the excess of carbonic acid in the escaping gases, and of oxygen and carbon at the lower depths he had referred to, had probably also proceeded from the dissociation of carbonic oxide in the presence of oxide of iron or metallic iron in the manner already described.

By way of controverting any such limit as one volume of carbonic acid to two of carbonic oxide for the ratio of these two gases escaping from the blast-furnace, reference had been made in page 591 of the paper to Styrian furnaces, in which, in a paper that he had himself read at Vienna (Iron and Steel Institute Journal 1882, page 534), he had mentioned 15 cwts. of charcoal as sufficing to produce one ton of pig-iron. In the present paper it appeared to be thence inferred that there must surely have been a great quantity of carbonic acid in the escaping gases, in order to account for so low a consumption as only 15 cwts. of charcoal. But on referring to Table 4, page 613 , it would be seen what an extraordinary amount of coke was absorbed in what he had called the variable sources of appropriation of heat. For the fusion of the slag in furnace $D$ the quantity of coke required was no less than $3 \cdot 673 \mathrm{cwts}$. per ton of pig-iron; and he might go on to point out that all those variables fluctuated greatly, according to the class of ore which was being smelted. Thus instead of requiring, like furnace $\mathrm{D}$, more than 90,000 calories per ton of pig-iron produced, the Styrian furnaces, using $15 \mathrm{cwts}$. of charcoal, required only 60,000 calories. It was therefore easy to understand how so small a consumption of charcoal might suffice, and how nevertheless the furnaces might still retain the ratio of one volume of carbonic acid to two of carbonic oxide or thereabouts, as happened in the gases escaping from the larger furnaces working in Cleveland with a higher consumption of fuel. 
(Sir Lowthian Bell, Bart.)

With regard to the quantity of fuel required for melting a ton of pig-iron, there appeared to him to be a mistake in the mode of making the calculation in page 604 of the paper. His own assumption had been that 330 calories were required to melt one cwt. of iron; and the author had properly multiplied that by 20 , and got 6,600 calories for melting a ton of iron; but then he proceeded to divide this product by the number 2,473 . It was true that 2,473 calories might be assumed as the product of burning carbon into carbonic oxide; but was all the heat in the blast to be neglected, and all the carbonic oxide that was burnt into carbonic acid? In point of fact, as he had already shown in Table 3 (page 611), the quantity of heat obtained from the coke and from the blast in furnace $D$, instead of being 2,473 calories, was 4,240 ; and when the 6,600 calories came to be divided by 4,240 , the result was something like $1 \frac{1}{2}$ cwt. of coke per ton of iron, instead of the $2.67 \mathrm{cwts}$. mentioned in the paper. It was stated in page 604 that in practice a good cupola could melt a ton of iron with less than 1 cwt. of coke; and although he had never succeeded in doing this himself, he would not question it, but would accept the assurance that it was done. The author however had taken no account at all of the fact that coke burnt in a cupola was burnt under different conditions from those under which it was burnt in a blast-furnace. In a low furnace, such as a cupola, he should himself be much surprised if the gases escaping did not contain a notable quantity of carbonic acid; and he need not point out the great difference which that would make in the consumption of fuel.

With reference to the remarks in page 602 of the paper about the reduction in the quantity of air in the furnace when working on lime, it seemed to be implied that this reduction was due to having converted the limestone beforehand into lime. In his own opinion however it was not due to that cause. The quantity of air consumed in the furnace when using limestone had been increased, not on account of the carbonic acid that was in the limestone, but because the furnace had then to burn $3 \frac{3}{4} \mathrm{crts}$. more coke per ton of pig-iron, which quite accounted for the difference in the quantity of blast required. 
Mr. E. Windsor Richards, Member of Council, said the question of using lime instead of limestone in the blast-furnace had often exercised the minds of blast-furnace managers. It would seem natural that by putting in a purer material an economy of fuel should result. In January 1885 he had determined to try the experiment upon five very large blast-furnaces at Eston, Nos. 4, 5, 6, 7, and 8, using Cleveland ironstone; and had continued the experiments till October 1885. The burden was not altered; the furnaces carried neither a lighter nor a heavier burden. The only result obtained was that the furnaces drove better; they turned out a larger quantity of iron per fortnight; but there was no economy whatever in fuel. The average make of iron per fortnight in the five furnaces together when using limestone was 6,505 tons, and their make of iron during the seventeen fortnights of using calcined lime was 7,220 tons : showing that each furnace made about 70 tons more per week. There was no economy whatever in the fuel, not even sufficient to pay for the cost of calcining, although very large kilns were used, of 45 or 50 feet height, which took perhaps only about one ton of small coal to calcine about 30 tons of Cleveland ironstone. Of course in times like the present, when about 10s, a ton more could be got for the pig-iron than formerly, ironmasters might like to be able to make the extra 70 tons per week; but this did not bear upon the present question. Not being himself a chemist, he was unable to say what the proportion of carbonic acid to carbonic oxide in the escaping gases should be; but a few years ago he had spent for

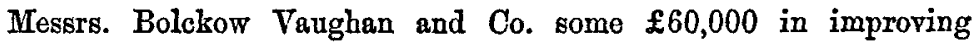
their six blast-furnaces at South Bank, and had naturally been anxious to obtain the best possible results. Reading and hearing a great deal about the proportions of earbonic acid to carbonic oxide, he thought he would try to have the proportion as nearly correct as possible; and so he employed Mr. Stead, whom all knew as one of the most careful chemists of the time. Observations were taken twice a day for about six months, which was no small matter; and the analysis of the gases showed that the proportion of carbonic acid to carbonic oxide varied every now and then, sometimes considerably. The blast-furnaces howerer did not take any notice 
(Mr. E. Windsor Richards.)

of the variation, but went on working remarkably well; and so he was obliged to leave it to others to settle the question of the precise proportion of the two gases. If it were possible to thrash out this question on neutral ground, he was sure that the proprietors of the Low Moor Iron Works would be very happy indeed to place one, two, or three of their cold-blast furnaces at the disposal of the President and Sir Lowthian Bell, in order that they might there ascertain whether there was any economy in using lime against limestone, and might also arrive at a solution of the vexed question as to the proportions of carbonic acid and carbonic oxide.

Mr. Edwand P. Mantin, Member of Council, gathered from the present paper that, while using caustic lime in a high blast-furnace might perhaps come to nothing, using caustic lime in low furnaces might have a bencficial effect. He intended trying it himself shortly in a low blast-furnace.

Mr. David Evans, having been connected with blast-furnaces all his life, agreed with Mr. Martin in thinking it an advantage to use lime in low furnaces. Formerly in South Wales he had been the manager of furnaces of 45 feet height at Aberdare and at Rhymney, and had found a considerable advantage in using lime; a larger output was obtained, and also, if he remembered rightly, a considerable saving in consumption of fuel. At Barrow, where he was now manager, nothing but limestone was being used, because there was no means of calcining it there; and therefore he could not express any opinion as to what economy there might be in using lime for smelting hematite ores in the Barrow furnaces of 60 to 65 feet height: although in the lower furnaces in South Wales of about 45 feet height considerable benefit had been found in using lime as against limestone.

Sir Lowthian Beli said he too had found benefit from using lime in the case of low blast-furnaces.

The President scarcely knew how to reply to much of what had been said. His difficulty arose from the introduction of matter 
which he had not introduced into his paper: especially those early experiments (pages 606-7) in reference to the effect of a mixture of carbonic acid and carbonic oxide upon oxide of iron and spongy iron respectively. He would admit unhesitatingly that Sir Lowthian Bell's experiments were correctly made and recorded; but they did not bear upon the blast-furnace in the proper conditions under which a blast-furnace ought regularly to work. There were of course circumstances in blast-furnace working where awkward conditions came into play; but what he aimed at was to remove the furnace from the sphere of operation of those awkward conditions; it was therefore beside the purpose of his paper to go further into that matter.

That Sir Lowthian Bell should have introduced the subject of highly heated air (page 610) was also a difficulty, because in the paper the temperature had been kept nearly the samo: the comparison had been made between two furnaces working on lime and on limestone with about the same temperature of blast, or as nearly so as could be practically obtained over two or three months at a time; and he had chosen the conditions so that there should be no objection raised to the fluctuation of temperature, and that there should be no corrections to make on that score at all; he had thus eliminated the question of blast temperature, and had not expected it to be raised. It was indeed superfiuous to discuss at the present day the old question fought out so long ago of the value of a high temperature of blast. It was pretty well admitted, by the general application of highly heated blast, that at any rate it had some merits ; but it did not bear at all upon his present paper.

As regarded the belief that caustic lime heated to a high temperature would absorb carbonic acid with great rapidity (page 612), this was an opinion against which he had all along had to fight; for he well recollected, from himself sitting at his feet twenty jears ago, how Sir Lowthian had then condemned the use of caustic lime, and had taken him to a kiln in which the lime was being burnt for testing the question, and had told him it was found perfectly useless to burn it, as it was not worth the trouble, and the kiln was consequently about to be let out. He was 
(The President.)

not surprised therefore to hear Sir Lowthian endorse that opinion now, and confirm it by even more recent experience. He had himself ever since had to fight against the prejudice so created in his own mind, that caustic lime ought not to be introduced into a blast-furnace; and he had therefore brought this paper forward to show that there were conditions under which caustic lime if properly applied would give more than the theoretical effect due to the saving of the carbonic acid expelled. This saving was clearly shown in the present paper, and in page 600 was given a detailed explanation of the $0.63 \mathrm{cwt}$. extra of carbon transferred from the condition of carbonic acid to that of carbonic oxide, beyond the $1.30 \mathrm{cwt}$. which obviously might fairly be supposed to represent the difference between the use of limestone and of lime. He had therefore considered it his duty to explain that there was something to be done with caustic lime after all. At the samo time he had to confess to its not being altogether an anmixed advantage. There were some disadvantages in working on lime; and in pages 601 and 602 he had endeavoured to point out where those disadvantages arose : namely that, although the carbonic acid of the limestone had been got rid of, and had thus been precluded from exerting any mischievous influence in the red-hot region of the furnace, nevertheless another element of mischief had been introduced in the shape of a less effective reduction of the ironstone. The carbonic acid when evolved in the red-hot region, whether resulting from the reduction of the ironstone or from the limestone, was equally damaging to the operations of the furnace, by causing the absorption of carbon in that region. Having himself found out the means by which these two mischievous influences could be separated and analysed, so as to say weight for weight what mischief was done by the one and by the other, the main object of his present paper was to indicate clearly the separation of these two items-the carbonic acid of reduction and the carbonic acid evolved from the limestone-and to point out the mischief done respectively by each.

As to any challenge (page 614) on the subject of the 23.28 corts. of coke consumed when limestone was used and only 19.49 cwts. when working on lime (page 595), he could only say this was a matter 
of fact which he could not dispute; he had found it on the face of the comparison, and had endeavoured to explain how the saving arose. The conditions under which the 23.28 cwts. of coke were being consumed when working on limestone were the same as those under which the $19 \cdot 49 \mathrm{cwts}$. were being consumed when working on lime. He had endeavoured to bring these facts forward as clearly as possible, and so that there could be no possibility of questioning the conditions under which the experiments were made.

As to that perfect reduction of the ironstone, which Sir Lowthian Bell alleged (page 615) to be impossible in the upper regions of the blast-furnace, he must say that, whatever the theory evolved from the laboratory might be, perfect reduction was possible in the upper regions, and was possible only, so far as he could see at present, by the use of limestone. Thus in page 601 he had pointed out that, when working on limestone, the proportion of ironstone reduced in the cooler regions of the furnace out of contact with red-hot coke was as much as 42.49 cwts. per ton of pig-iron, whilst only $7 \cdot 64$ cwts. passed down into the red-hot zone for reduction there; whereas, when working on lime, the larger figure had fallen to $35.84 \mathrm{cwts.}$, and the smaller had risen to $14 \cdot 16 \mathrm{cwts}$. In the same page 601 he had given the reason, namely that the use of limestone absolutely created an amplified reducing region, owing to the largely increased weight of carbonic oxide per ton of pig-iron, which was obtained from the carbonic acid of the limestone and was operating in favour of a more effective reduction of the ironstone. Hence when working on lime the furnace was robbed of so much carbonic oxide in the reducing region, occasioning thereby a loss in the reduction of the ironstone in the cool region of reduction. On the other hand the previous expulsion of the carbonic acid from the fux outweighed favourably the disadvantage in reducing the ironstone less efficiently: so that on the whole the furnace could carry an extra burden, and produce an increased output of iron with an economy of coke, at the same rate of driving. He claimed only to have pointed out the exact limits where the furnace lost in the one case and gained in the other. The use of limestone was not an unmixed good, and it was not an unmixed evil. It conferred some 
(The President.)

benefits; but when the balance of benefits and evils was taken, it was in favour of the use of lime to the extent which he had shown. If only the mischief due to the diminished weight of carbonic oxide when working on lime could have been avoided, the economy of coke would have been more than 3.75 cwts. per ton of pig-iron; it ought to have been nearer $5 \mathrm{cwts}$. than $3.75 \mathrm{cwts.}$, had he succeeded in the best anticipations held forth in his former paper in 1883. In his present paper he had sought to show wherein he had failed and how far, and also to show the extent to which he had succeeded.

In regard to the dissociation of carbonic oxide in the presence of spongy iron at a high temperature, to which Sir Lowthian Bell had referred (page 615), he had always had his eye upon this, being indebted to Sir Lowthian for having pointed out the danger of such dissociation in the upper part of the furnace; and he had himself absolutely ascertained when it was most likely to occur. The experiments he had made were free he believed from any dissociation whatever of carbonic oxide, due to the presence of spongy iron. The observations made daily and twice a day had simply been rejected whenever the furnace was working irregularly and when the dissociation took place. It had puzzled him for a couple of years before he could identify Sir Lowthian Bell's laboratory experiments with his own blast-furnace experiments; and having regarded as due to dissociation of carbonic oxide a higher ratio of carbonic acid to carbonic oxide than what could be due to normal work, he had taken no notice of the week's or month's observations while the furnace was working in such an abnormal condition. He was indebted to Sir Lowthian Bell for having pointed out that dissociation; and to his own observations for having discovered how it could be seen in the blast-furnace. Noreover in reference to Sir Lowthian's Table 5, page 616, given in confirmation of his theory that dissociation of carbonic oxide took place as far down as 68 feet depth, he would venture to suggest that the true source of the slightly increased quantity there shown of carbon and oxygen in the gases was to be found-either in the carbonic acid contained within the core of a piece of limestone, from 
which it was unexpelled until it reached that great depth; or in the unreduced core of a piece of imperfectly calcined ironstone, containing both oxygen and carbon; or finally, so far as oxygen was concerned, in the unexpelled oxygen from the refractory core of a fused mass of ironstone.

With regard to the coke burnod in the cupola (page 618), he had recalled on a previous occasion (Proceedings 1883, page 135) the simple law to which attention had been directed several years ago in the journal Iron (5 January 1883, page 19): namely that at a temperature of about $2300^{\circ}$ Fahr. or between $1200^{\circ}$ and $1300^{\circ}$ centig. carbonic acid could not exist; it was dissociated instantly into carbonic oxide and oxygen. Hence his starting proposition was that the whole of the coke in the blast-furnace was immediately burned into carbonic oxide, because carbonic acid could not exist there. The conditions of a cupola were precisely the same; carbonic acid could not exist at the temperature at which it was necessary to melt the iron and slag coming down in a cupola. What was seen any evening in the dusk in the beautiful blue flame at the top of a cupola was carbonic oxide given off free, and there burning into carbonic acid. It could be seen on a frosty night in an ordinary coal fire in the house : the carbonic oxide was creeping away from the coals, and had to rise two or three inches above them before it became cool enough to burn further into carbonic acid. The carbonic acid could not be formed until the carbonic oxide was sufficiently cooled down to unite with oxygen. It was the same in the cupola and in the blastfurnace, in which the carbonic acid was dissociated because at that temperature it could not exist as carbonic acid; there could be nothing but carbonic oxide in those hot regions. Hence he had made no experiments on this point, believing that in regular work foundry cupolas could be found to melt 1 ton of pig-iron with 1 cwt. of coke, exclusive of filling in. The blast-furnace ought to melt iron with $1 \mathrm{cwt}$. to $1.1 \mathrm{cwt}$., according to the quality of the coke.

On the subject of the difference (page 615) in the working of the same blast-furnace on limestone with the moderate consumption in 
(The President.)

May 1882 of 21.45 ewts. of coke per ton of pig-iron (Proceedings 1883, page 119), as compared with the $23 \cdot 28 \mathrm{cwts}$. given in the present paper for the same furnace still working on limestone, he would refer to the respective analyses of the working of the furnace at the former and the later period; and would call attention to the fact that in the former only $2.00 \mathrm{cwts}$. of carbon suffered transfer from the condition of carbonic acid to that of carbonic oxide, against $2.44 \mathrm{cwts}$. in the later period. The carbon absorbed by the carbonic acid of the flux was in 1882 only $1.33 \mathrm{cwt}$. instead of $1.52 \mathrm{cwt}$., owing to an increased consumption of limestone in the latter case. The slag in 1882 absorbed only $6 \cdot 67$ cwts. against $7 \cdot 11$ cwts. latterly. All this was due mainly to a change in the character of the ironstone employed, and its greater richness in iron in 1882. No greater confirmation could be found of the views advanced in the present paper than the following working out of the above figures, bearing in mind that every unit of carbon once existing as carbonic acid and afterwards re-converted into carbonic oxide (page 592) represented a total loss to the furnace efficiency of $2 \cdot 26$ units of carbon burnt into carbonic oxide:- $\{(2 \cdot 44-2 \cdot 00)+(1 \cdot 52-$ $1 \cdot 33)\} \times 2 \cdot 26=1 \cdot 42$ cwts. and $1.42+7 \cdot 11-6 \cdot 67=1.86$ cwts. thus accounted for as the difference between the former and the later working. The actual difference to which Sir Lowthian Bell had drawn attention (page 615) was $23 \cdot 28-21 \cdot 45=1 \cdot 83$ cwts., which was due solely to the inferior ironstone employed at the later period. Thus the later extra consumption of coke was fully accounted for.

In Mr. Windsor Richards's observations (page 619) he found one confirmation of his own results, and he was pleased to seize it and call attention to it: namely that he admitted an increased make from 6,505 to 7,220 tons of pig-iron per fortnight, which was an increase of 11 per cent. All that he had himself claimed in his paper (page 603) was 14 per cent. The failure to accomplish at Eston, in proportion to the quantity of flux employed, a saving of fuel corresponding with that which he had realised at Ormesby, might be owing to the fact that the matter was one requiring the greatest care and long trial; and he had no doubt further experience 
would result in an economy of fuel proportional to the quantity of limestone employed in a calcined state.

Sir Lowthian BeLl asked whether there was anything peculiar in the mode of introducing the calcined ironstone into the furnace. Also did the author agree that the $330 \times 20=6,600$ calories for melting a ton of pig-iron should be divided by the total heating power of the coke, instead of by 2,473 only, which was little more than one-third of the total heat-units in coke? And similarly in regard to the melting of the slag?

The Presidenn replied that the ironstone had been dealt with throughout the paper as already calcined when charged into the blast-furnace, according to the regular practice.

The practical heating power to be assigned to the coke for melting the iron and slag was the old rexed question on which he had differed from Sir Lowthian Bell from the outset. In Sir Lowthian's practice, as was evident from going through his papers, if a certain quantity of carbonic acid was developed and a certain quantity of carbonic oxide, he had taken the sum of the units of heat developed by the evolution of carbonic acid and by the evolution of carbonic oxide, and had divided it by the total quaitity of coke burnt, and had regarded the quotient as the average number of units of heat to be accounted for in the blast-furnace. In his own practice however the very first thing that he had set himself to do had been to cast off the idea that any such average should be adopted; for he fancied that he saw that beneath any such average would be buried all the means of ascertaining what was at present behind the veil. Having then cast off that idea, what he had immediately made up his mind to do was this: the blast-furnace managers did not deal much with units. of heat, but they could see and know the value of each cwt. of coke used to smelt one ton of iron in a blast-furnace; and if there was any economy possible, they would take care to seize it. Therefore, knowing that 2,473 units of heat were developed by the combustion of carbon into carbonic oxide, and that all fuel reaching the tuyeres 
(The President.)

was there burnt into carbonic oxide, he had adopted carbonic oxide as the sole basis for calculation. In thus abandoning Sir Lowthian Bell's plan of averaging the heat-units according to the amount of carbonic acid and carbonic oxide conjointly, he had had to persuade himself against Sir Lowthian's conviction to the contrary; and the present paper was the outcome of the efforts he had made in this direction.

Taking furnace D, which Sir Lowthian Bell had quoted (page 614) from Table 4 in condemnation of the method. of calculation followed in the paper, and accepting his total of 90,057 calories as correct, the division of this number by the standard of 2,473 heat-units, developed by the combustion of carbon into carbonic oxide, would give the total result of $36.42 \mathrm{cwts}$. of carbon consumed per ton of pig-iron, instead of the actual consumption stated in the table of only 21.24 cwts. of coke. The $36.42 \mathrm{cwts}$. of carbon would have been the consumption, had no heat been carried in by the blast, and had no carbonic oxide been burnt in the furnace into carbonic acid with its consequent extra development of heat. But Table 4 showed that $94 \mathrm{cwts}$. of air were carried into furnace $\mathrm{D}$ at a temperature of $695^{\circ}$ centig., which would represent $94 \times 695 \times 0.239 \div 2,473=$ 6.31 ewts. of carbon burnt into carbonic oxide. It had further been shown in the paper (page 592) that every cwt. of carbon burnt from carbonic oxide into carbonic acid must save $1.26 \mathrm{cwt}$. of carbon burnt into carbonic oxide at the tuyeres; and assuming perfect reduction of the ironstone to have taken place in furnace $D$, 6.04 cwts. of carbon (page 593) would exist as carbonic acid : so that the economy at the tuyeres would be $6.04 \times 1.26=7 \cdot 61 \mathrm{cwts}$ of carbon burnt into carbonic oxide. Hence the heat carried in by the blast and that developed by combustion of carbonic oxide into carbonic acid would be together equivalent to $6 \cdot 31+7 \cdot 61=$ 13.92 cwts. of carbon; and allowing 10 per cent. for ash in the coke, there would be $13.92 \times 100 \div 90=15.47 \mathrm{cwts}$. of coke to be added to the actual consumption of $21 \cdot 24 \mathrm{cwts}$. of coke, making the total of 36.71 cwts. of coke. This result was in fair agreement with the $36.42 \mathrm{cwts}$. of carbon, or $36.42 \times 100 \div 90=40.47$ cwts. of coke, which he had calculated from the total of 90,057 
calories given in Table 4. A more exact comparison could not be made unless all the conditions of working in furnace $D$ were known.

In regard to Sir Lowthian Bell's doubt (page 615) about the possibility of obtaining perfect reduction of the ironstone, he would direct attention to Professor Grüner's observation* upon the second example of Sir Lowthian's own practice at the Clarence Iron Works, wherein M. Grüner found that not only was that furnace reducing perfectly all the ironstone, but that the total carbon absorbed in converting carbonic acid back into carbonic oxide was actually less than existed in the limestone, which proved that the whole carbonic acid of the limestone was not necessarily converted into carbonic oxide in the furnace. It was to this slight excess of carbonic acid that he had made reference in page 594 of the paper as a trifling wave of carbonic acid removed from the limestone before it reached the region of red-hot coke; and he repeated that on several occasions he had observed a like condition in the blast-furnace practice at Ormesby, whilst from the nature of the circumstances it was impossible that dissociation of carbonic oxide could have entered prejudicially into the case.

Mr. Joseph Tomrinson, Vice-President, occupying the chair during the discussion upon the President's paper, had no doubt the Members would gladly join with him in cordially thanking the President for his paper, and also in thanking Sir Lowthian Bell for his remarks respecting it. The question from its very nature was a vexed one, as to what went on inside a blast-furnace of 80 feet height when it was in full work. Therefore some diversity of opinion must be expected; and without such discussions as that which had just taken place, the degree of perfection which had now been attained in blast-furnace working could not have been arrived at. He feared the President and Sir Lowthian Bell would not be able to avail themselves of Mr. Windsor Richards's offer (page 620) to allow them

* Grüner's Studies of Blast-Furnace Phenomena; Gordon's translation (1873), $\S 17$, page 44 , foot-note. 
(Mr. Joseph Tomlinson.)

to experiment on the blast-furnaces at Low Moor, because whether open-topped or closed they did not work with hot blast, and therefore the circumstances were widely different from those of the Cleveland blast-furnaces. 